\title{
Identification of a minimal microsatellite marker panel for the fingerprinting of peach and nectarine cultivars
}

\author{
Gabriela Rojas \\ Laboratorio de Biotecnología \\ INIA CRI La Platina \\ Av. Santa Rosa \#11610, La Pintana \\ Santiago, Chile \\ Tel: 5627575129 \\ Fax: 5627575139 \\ E-mail: grojas@inia.cl \\ Marco A. Méndez \\ Laboratorio de Genómica Evolutiva \\ INTA - Universidad de Chile \\ Av. Macul \#5540, Macul \\ Santiago, Chile \\ Tel: 5629781552 \\ Fax: 5622214030 \\ E-mail: mmendez@inta.cl

\section{Carlos Muñoz} \\ Departamento de Fitomejoramiento y Biotecnología \\ INIA CRI La Platina \\ Av. Santa Rosa \#11610, La Pintana \\ Santiago, Chile \\ Tel: 5627575157 \\ Fax: 5627575139 \\ E-mail: cmunoz@inia.cl

\section{Gamalier Lemus} \\ INIA CRI La Platina \\ Av. Santa Rosa \#11610, La Pintana \\ Santiago, Chile \\ Tel: 5627575143 \\ Fax: 5627575139 \\ E-mail: glemus@inia.cl

\section{Patricio Hinrichsen*} \\ Laboratorio de Biotecnología \\ INIA CRI La Platina \\ Av. Santa Rosa \#11610, La Pintana \\ Santiago, Chile \\ Tel: 5627575110 \\ Fax: 5627575139
}

Financial support: Financed by FONDEF-Chile, Grant D04I-1060.

Keywords: cultivar identification, fingerprinting, Prunus persica, simple sequence repeats, SSR.

Abbreviations: AFLP: amplified length polymorphism

IP: intellectual property

PCR: polymerase chain reaction

S-SAP: sequence-specific amplification polymorphism

SSR: simple sequence repeats

The genetic characterization of 117 peach and nectarine cultivars (Prunus persica (L.) Batsch) using microsatellite (SSR) markers is presented. Analyzed genotypes include the complete list of cultivars under intellectual property (IP) protection in Chile. One hundred and two out of the 117 cultivars under study could be identified using only 7 SSRs. Other 5 cultivars were differentiated using 3 additional markers, but 5

*Corresponding author 
pairs of genotypes were not differentiable. The average expected heterozygosity for the set of markers was 0.55 , ranging from 0.28 in BPPCT-008 to 0.81 in CPPCT-022, with an $F$ value of 0.37 . A Neighbor-Joining dendrogram showed that, with few exceptions, peaches and nectarines clustered separately. These results are the basis for the development of a fingerprinting protocol for the unequivocal identification of most of the peach and nectarine cultivars officially registered in Chile.

Peaches and nectarines (Prunus persica (L.) Batsch) are among the most important fruit crops of temperate climates. Modern breeding of this species began in the USA towards the end of the $19^{\text {th }}$ Century, based on a very limited number of genotypes. Because of this and because of its high degree of natural self-pollination, peach cultivars are known to have a quite narrow genetic base (Scorza et al. 1985; Scorza et al. 1988). In contrast, there are a larger number of peach and nectarine cultivars compared with other fruit crops, due to a very intense breeding activity developed worldwide during many decades. For example, almost 500 new cultivars were released around the world from 1990 to 1996 (Fideghelli et al. 1998).

To avoid misidentification of cultivars and to protect plant varieties owners' IP rights, efficient tools are needed such as DNA fingerprinting. The large number of cultivars and their very limited genetic diversity make cultivar differentiation and fingerprinting of this species particularly challenging. Microsatellites or simple sequence repeats (SSRs) are up to now the most powerful tool available for fingerprinting because of their characteristics of ubiquitous distribution along the eukaryotic genomes, high level of polymorphism, co-dominant inheritance, high discrimination power and easiness of detection (Morgante and Olivieri, 1993). A number of SSR markers for $P$. persica and other species of the same genus have been described until now, making hundreds of these markers available for different purposes (Cipriani et al. 1999; Sosinski et al. 2000; Testolin et al. 2000; Aranzana et al. 2002; Dirlewanger et al. 2002). These markers have been used for fingerprinting of peaches and nectarines (Cipriani et al. 1999; Aranzana et al. 2003a), apricots (Messina et al. 2004), plums (Decroocq et al. 2004; Mnejja et al. 2004), cherries (Wünsch and Hormaza, 2002; Vaughan and Rusell, 2004), and almonds (Testolin et al. 2004). Also, they have been used to construct inter- (Foolad et al. 1995; Dirlewanger et al. 2004) and intra-specific linkage maps (Howad et al. 2005), and their on the Prunus genetic map have been determined for most of them (Aranzana et al. 2003a). Some of the SSR markers isolated from peach have been used in other species of Prunus (Downey and Iezzoni, 2000) and vice versa, according to the close genetic relationships between Prunus species. This is very convenient because there exists a chance to apply the same set of markers to identify cultivars in different Prunus species, as well as in inter-specific hybrids used as rootstocks.

Aranzana et al. (2003b) characterized and differentiated over 200 cultivars of peaches and nectarines commonly grown in Spain, using a selected set of 16 microsatellite markers. Cultivars grown in Chile come mainly from North American breeding programs. So, when we considered the $100+$ most planted cultivars in Chile it was found that less than $10 \%$ where shared by the set of Spanish cultivars previously characterized. Assuming that the Spanish varieties derived from a different genetic background respect of the American varieties, we hypothesized that the set of markers used by Aranzana et al. (2003b) would probably not have the best performance to identify the varieties registered in Chile. Therefore the purpose of this work was to determine to what extent the set of SSR markers used elsewhere can be useful to differentiate the main peach and nectarine cultivars grown in Chile and to find out the minimal set of markers that could afford this task. Also, in doing that we would be able to determine the genetic diversity of the of $P$. persica germplasm present in Chile.

\section{MATERIALS AND METHODS}

\section{Plant material}

A total of $117 \mathrm{P}$. persica cultivars, 64 peaches and 53

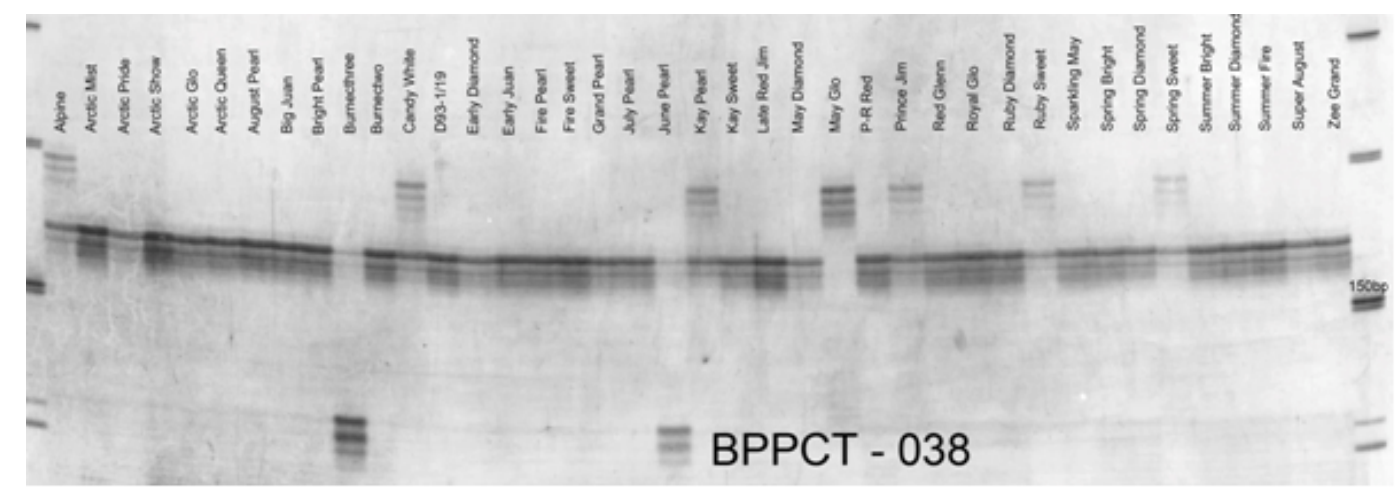

Figure 1. Microsatellite pattern of nectarine cultivars for the marker BPPCT-038. 
Table 1. List of peach and nectarine cultivars used in this study.

\begin{tabular}{|c|c|c|c|c|c|}
\hline Cultivar & Source & Fruit & Cultivar & Source & Fruit trait $^{\mathrm{a}}$ \\
\hline Andros & local nursery & $\mathrm{P}$ & Alpine-RVP & RVP-SAG & $\mathrm{N}$ \\
\hline Andross-RVP & RVP-SAG ${ }^{b}$ & $\mathrm{P}$ & Arctic Mist-RVP & RVP-SAG & $\mathrm{N}$ \\
\hline August Lady-RVP & RVP-SAG & $\mathrm{P}$ & Arctic Pride-RVP & RVP-SAG & $\mathrm{N}$ \\
\hline Autumn Flame-RVP & RVP-SAG & $\mathrm{P}$ & Arctic Show-RVP & RVP-SAG & $\mathrm{N}$ \\
\hline Bowen & local nursery & $\mathrm{P}$ & Artic Glo-RVP & RVP-SAG & $\mathrm{N}$ \\
\hline Bowen-RVP & RVP-SAG & $\mathrm{P}$ & Artic Queen-RVP & RVP-SAG & $\mathrm{N}$ \\
\hline Burpeachfour-RVP & RVP-SAG & $P$ & Artic Snow & local nursery & $\mathrm{N}$ \\
\hline Burpeachone-RVP & RVP-SAG & $\mathrm{P}$ & August Pearl-RVP & RVP-SAG & $\mathrm{N}$ \\
\hline Burpeachsix-RVP & RVP-SAG & $P$ & August Red & RVP-SAG & $\mathrm{N}$ \\
\hline Burpeachthree-RVP & RVP-SAG & $\mathrm{P}$ & Big Juan-RVP & RVP-SAG & $\mathrm{N}$ \\
\hline Burpeachtwo-RVP & RVP-SAG & $\mathrm{P}$ & Bright Pearl-RVP & RVP-SAG & $N$ \\
\hline Cal Red & local nursery & $P$ & Burnecthree-RVP & RVP-SAG & $N$ \\
\hline Carson & local nursery & $P$ & Burnectwo-RVP & RVP-SAG & $\mathrm{N}$ \\
\hline Carson-RVP & RVP-SAG & $\mathrm{P}$ & Candy White-RVP & RVP-SAG & $\mathrm{N}$ \\
\hline Corona & local nursery & $P$ & D 93-1/19-RVP & RVP-SAG & $\mathrm{N}$ \\
\hline Corona-RVP & RVP-SAG & $\mathrm{P}$ & Early Diamond-RVP & RVP-SAG & $\mathrm{N}$ \\
\hline Crown Princess-RVP & RVP-SAG & $P$ & Early Juan-RVP & RVP-SAG & $\mathrm{N}$ \\
\hline Dee Six - 15W-RVP & RVP-SAG & $\mathrm{P}$ & Fiesta & local nursery & $\mathrm{N}$ \\
\hline Diamond Princess-RVP & RVP-SAG & $\mathrm{P}$ & Fire Pearl-RVP & RVP-SAG & $\mathrm{N}$ \\
\hline Dixon & local nursery & $\mathrm{P}$ & Fire Sweet-RVP & RVP-SAG & $\mathrm{N}$ \\
\hline Doctor Davis & local nursery & $P$ & Grand Pearl-RVP & RVP-SAG & $\mathrm{N}$ \\
\hline Dr Davis-RVP & RVP-SAG & $\mathrm{P}$ & July Pearl-RVP & RVP-SAG & $\mathrm{N}$ \\
\hline Earlirich-RVP & RVP-SAG & $P$ & June Pearl-RVP & RVP-SAG & $\mathrm{N}$ \\
\hline Early Magestic & local nursery & $\mathrm{P}$ & Kay Pearl-RVP & RVP-SAG & $\mathrm{N}$ \\
\hline Elberta-RVP & RVP-SAG & $P$ & Kay Sweet-RVP & RVP-SAG & $\mathrm{N}$ \\
\hline Elegant Lady & local nursery & $\mathrm{P}$ & Late Red Jim-RVP & RVP-SAG & $\mathrm{N}$ \\
\hline Elegant lady-RVP & RVP-SAG & $\mathrm{P}$ & May Diamond-RVP & RVP-SAG & $\mathrm{N}$ \\
\hline Everts-RVP & RVP-SAG & $\mathrm{P}$ & May glo-RVP & RVP-SAG & $\mathrm{N}$ \\
\hline Flavor Crest & local nursery & $\mathrm{P}$ & Nectar Crest & local nursery & $N$ \\
\hline Flordagrand-RVP & RVP-SAG & $\mathrm{P}$ & P-R Red-RVP & RVP-SAG & $N$ \\
\hline Halford-RVP & RVP-SAG & $P$ & Prince Jim-RVP & RVP-SAG & $\mathrm{N}$ \\
\hline Ito Red-RVP & RVP-SAG & $\mathrm{P}$ & Red Diamond & local nursery & $\mathrm{N}$ \\
\hline Ivory Princess-RVP & RVP-SAG & $\mathrm{P}$ & Red Glenn-RVP & RVP-SAG & $\mathrm{N}$ \\
\hline
\end{tabular}


Rojas, G. et al.

\begin{tabular}{|c|c|c|c|c|c|}
\hline Klamp & local nursery & $P$ & Rio & local nursery & $\mathrm{N}$ \\
\hline Klampt-RVP & RVP-SAG & $P$ & Royal Delight & local nursery & N \\
\hline Land Reth-RVP & RVP-SAG & $P$ & Royal Glo-RVP & RVP-SAG & $\mathrm{N}$ \\
\hline Lindo & local nursery & $P$ & Ruby Diamond-RVP & RVP-SAG & N \\
\hline Loadell & local nursery & $P$ & Ruby Sweet-RVP & RVP-SAG & N \\
\hline Loadell-RVP & RVP-SAG & $P$ & September Lady & local nursery & $\mathrm{N}$ \\
\hline Loadel-RVP & RVP-SAG & $P$ & Sparkling May-RVP & RVP-SAG & N \\
\hline Manon & local nursery & $P$ & Spring Bright-RVP & RVP-SAG & N \\
\hline Monaco-RVP & RVP-SAG & $P$ & Spring Diamond-RVP & RVP-SAG & $\mathrm{N}$ \\
\hline Pomona & local nursery & $P$ & Spring Red & local nursery & $\mathrm{N}$ \\
\hline Queen Crest -RVP & RVP-SAG & $P$ & Spring Sweet-RVP & RVP-SAG & N \\
\hline Reigels-RVP & RVP-SAG & $P$ & Summer Bright-RVP & RVP-SAG & N \\
\hline Rich Lady-RVP & RVP-SAG & $P$ & Summer Diamond & local nursery & N \\
\hline Rich May-RVP & RVP-SAG & $P$ & Summer Diamond-RVP & RVP-SAG & $\mathrm{N}$ \\
\hline Robin Neil-RVP & RVP-SAG & $P$ & Summer Fire-RVP & RVP-SAG & N \\
\hline Rome Star-RVP & RVP-SAG & $P$ & Sun Grand & local nursery & $\mathrm{N}$ \\
\hline Ross Peach & local nursery & $P$ & Sun Rise & local nursery & $\mathrm{N}$ \\
\hline Ross Peach-RVP & RVP-SAG & $P$ & Super August-RVP & RVP-SAG & N \\
\hline Ross-RVP & RVP-SAG & $P$ & Super Queen & local nursery & $\mathrm{N}$ \\
\hline Ryan Sun-RVP & RVP-SAG & $P$ & Zee Grand-RVP & RVP-SAG & N \\
\hline Scarlet Snow-RVP & RVP-SAG & $P$ & & & \\
\hline September Snow-RVP & RVP-SAG & $P$ & & & \\
\hline September Sun-RVP & RVP-SAG & $P$ & & & \\
\hline Snow King-RVP & RVP-SAG & $P$ & & & \\
\hline Snow Princess-RVP & RVP-SAG & $P$ & & & \\
\hline Sullivan \#4-RVP & RVP-SAG & $P$ & & & \\
\hline Summer Lady-RVP & RVP-SAG & $P$ & & & \\
\hline Sweet September-RVP & RVP-SAG & $P$ & & & \\
\hline TUFTS-RVP & RVP-SAG & $P$ & & & \\
\hline Western Sun-RVP & RVP-SAG & $P$ & & & \\
\hline Wisser-RVP & RVP-SAG & $\mathrm{P}$ & & & \\
\hline
\end{tabular}

${ }^{a} \mathrm{P}$ : peach, $\mathrm{N}$ : nectarine.

${ }^{\mathrm{b}}$ RVP-SAG: Registro de Variedades Protegidas of SAG-Chile.

nectarines, were used in this study (Table 1). Most of them (88) came from the Chilean Registry of Protected Varieties, of the Ministry of Agriculture (RVP-SAG) and the rest were obtained from various nurseries. For plant DNA extraction, leaf samples were collected from actively growing shoots during late spring to early summer, transported to the laboratory in refrigerated containers and immediately stored at $-80^{\circ} \mathrm{C}$. 


\section{Plant DNA extraction, PCR amplification and electrophoretic fragment separation}

Genomic DNA was extracted following the method described by Lodhi et al. (1994). Extracted genomic DNA was PCR-amplified using 9 pairs of microsatellite primers (Table 2). PCR reactions were performed in $16 \mu$ l volumes containing $20 \mathrm{mM}$ Tris- $\mathrm{HCl}$ (pH 8.4), $50 \mathrm{mM} \mathrm{KCl}, 1.5 \mathrm{mM}$ $\mathrm{MgCl}_{2}, 1 \mathrm{mM}$ dNTPs, 50 pmol each primer, $20 \mathrm{ng}$ genomic DNA, $0.5 \mu 1 \mathrm{Taq}$ polymerase. Reactions were carried out on a Mastercycler Eppendorf thermocycler using the following temperature profile: an initial step of $5 \mathrm{~min}$ at $95^{\circ} \mathrm{C}, 35$ cycles of $30 \mathrm{sec}$ at $94^{\circ} \mathrm{C}, 30 \mathrm{sec}$ at $56^{\circ} \mathrm{C}$ and $30 \mathrm{sec}$ at $72^{\circ} \mathrm{C}$, and a final step of $5 \mathrm{~min}$ at $72^{\circ} \mathrm{C}$. The PCR products were then denatured by the addition of $0.5 \mathrm{vol}$ of 95\% formamide/dye solution (loading dye: $95 \%$ deionized formamide, $10 \mathrm{mM}$ EDTA, $0.1 \%$ xylene cyanol), heating for $5 \mathrm{~min}$ at $94^{\circ} \mathrm{C}$, chilled on ice and then $6 \mu \mathrm{l}$ of the denatured preparation were loaded on a $6 \%$ polyacrylamide gels containing $7.5 \mathrm{M}$ urea in $0.5 \mathrm{X}$ TBE buffer $(90 \mathrm{mM}$ Tris, $90 \mathrm{mM}$ boric acid, $2 \mathrm{mM}$ EDTA). Gels were run for approximately $2 \mathrm{hrs}$ at $85 \mathrm{~W}$. Following electrophoresis, the gel was silver-stained according to the protocol described by Creste et al. (2001). Fragment sizes were estimated by comparison with known allelic patterns.

\section{Data analysis}

The parameters used to evaluate the information given by the 9 SSRs studied were the number of alleles (A) and the effective number of alleles $\left(\mathrm{A}_{\mathrm{e}}\right)$ per locus $\left(\mathrm{A}_{\mathrm{e}}=1 / \Sigma p i^{2}\right.$, where $p i$ is the frequency of the $i^{\text {th }}$ allele), the observed heterozygosity $\left(\mathrm{H}_{\mathrm{o}}=\right.$ number of heterozygous individuals/number of individuals scored), the expected

Table 2. Microsatellite primer pairs used for the analyses of peach and nectarines genotypes.

\begin{tabular}{|c|c|c|c|c|}
\hline Locus & Primer Sequence 5' - 3' & Allelic size range $(\mathrm{pb})$ & $\mathrm{T}_{\mathrm{a}}\left({ }^{\circ} \mathrm{C}\right)$ & Reference \\
\hline \multirow{2}{*}{ BPPCT-001 } & AAT TCC CAA AGG ATG TGT ATG AG & \multirow{2}{*}{$128-168$} & \multirow{2}{*}{56} & \multirow{2}{*}{ Dirlewanger et al. 2002} \\
\hline & CAG GTG AAT GAG CCA AAG C & & & \\
\hline \multirow{2}{*}{ BPPCT-006 } & GCT TGT GGC ATG GAA GC & \multirow{2}{*}{$111-137$} & \multirow{2}{*}{56} & \multirow{2}{*}{ Dirlewanger et al. 2002} \\
\hline & CCС TGT TTC TCA TAG AAC TCA CAT & & & \\
\hline \multirow{2}{*}{ ВPPCT-007 } & TCA TTG CTC GTC ATC AGC & \multirow{2}{*}{$124-147$} & \multirow{2}{*}{56} & \multirow{2}{*}{ Dirlewanger et al. 2002} \\
\hline & CAG ATT TCT GAA GTT AGC GGT A & & & \\
\hline \multirow{2}{*}{ BPPCT-008 } & ATG GTG TGT ATG GAC ATG ATG A & \multirow{2}{*}{$99-160$} & \multirow{2}{*}{56} & \multirow{2}{*}{ Dirlewanger et al. 2002} \\
\hline & CCT CAA CCT AAG ACA CCT TCA CT & & & \\
\hline \multirow{2}{*}{ ВРPCT-038 } & TAT ATT GTT GGC TTC TTG CAT G & \multirow{2}{*}{135} & \multirow{2}{*}{56} & \multirow{2}{*}{ Dirlewanger et al. 2002} \\
\hline & TGA AAG TGA AAC AAT GGA AGC & & & \\
\hline \multirow{2}{*}{ СРРСТ-022 } & CAA TTA GCT AGA GAG AAT TAT TG & \multirow{2}{*}{$249-297$} & \multirow{2}{*}{56} & \multirow{2}{*}{ Aranzana et al. 2002} \\
\hline & GAC AAG AAG CAA GTA GTT TG & & & \\
\hline \multirow{2}{*}{ СРРСТ-029 } & CСA AAT TCС AAA TCT ССТ AAC A & \multirow{2}{*}{$170-194$} & \multirow{2}{*}{52} & \multirow{2}{*}{ Aranzana et al. 2002} \\
\hline & TGA TCA ACT TTG AGA TTT GTT GAA & & & \\
\hline \multirow{2}{*}{ СРРСТ-030 } & TGA ATA TTG TTC CTC AAT TC & \multirow{2}{*}{$170-200$} & \multirow{2}{*}{52} & \multirow{2}{*}{ Aranzana et al. 2002} \\
\hline & CTC TAG GCA AGA GAT GAG A & & & \\
\hline \multirow{2}{*}{ PMS-67 } & AGT CTC TCA CAG TCA GTT TCT & \multirow{2}{*}{$144-191$} & \multirow{2}{*}{56} & \multirow{2}{*}{ Cantini et al. 2001} \\
\hline & ТTA АСТ ТАA ССС СТС ТСС СТС С & & & \\
\hline
\end{tabular}

${ }^{\mathrm{a}} \mathrm{T}_{\mathrm{a}}$ : annealing temperature. 
heterozygosity $\left(\mathrm{H}_{\mathrm{e}}=1-\Sigma p i^{2}\right)$ and Wright's fixation index $\left(\mathrm{F}=1-\mathrm{H}_{\mathrm{o}} / \mathrm{H}_{\mathrm{e}}\right)$.

To compare the efficiency of the markers in varietal identification, we estimated the discrimination power (D) of each primer as in Tessier et al. (1999):

$\mathrm{C}_{j}$ (confusion probability for the $j^{\text {th }}$ primer) is equal to the sum of the different $c_{i}$ for all $I$ patterns generated by the primer:

$$
C_{j}=\sum_{i=1}^{1} c_{i}=\sum_{i=1}^{1} p_{i} \frac{\left(N p_{i}-1\right)}{N-1}
$$

Where $p i$ is the frequency of the $i^{\text {th }}$ allele and $\mathrm{N}$ is the number of individuals scored.

Thus, the discriminating power of the $j^{\text {th }}$ primer is equal to:

$\mathrm{D}_{j}=1-\mathrm{C}_{j}$

Total number of non-differentiated pairs of varieties for the $j^{\text {th }}$ primer is given by:

$x_{j}=(\mathrm{N}(\mathrm{N}-1) / 2) C_{j}$

For a given combination of $k$ primers, $X k$ is equal to:

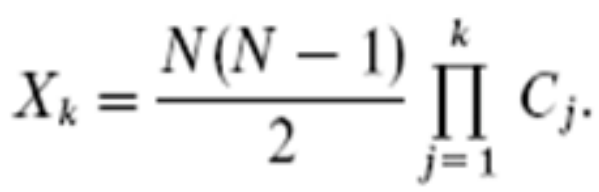

Abinary matrixwas constructed based on the presence/absence of microsatellite alleles. Phylogenetic trees were performed using the Neighbor Joining method with PAUP 4.0b software (Swofford, 1998).

\section{RESULTS}

\section{Microsatellite polymorphism}

A total of 117 peach cultivars were analyzed with 9 informative microsatellite markers. These 9 markers were previously selected as the most polymorphic from a larger set of SSRs, after evaluating a sub-sample of ca. 30 peach and nectarine cultivars (results not shown). Alleles were clearly differentiated by polyacrylamide gel electrophoresis. The separation of the amplicons for BPPCT-038 is shown as an example in Figure 1.

The statistical parameters obtained for the SSR markers used in this study are presented in Table 3. These SSRs amplified 59 alleles on this population of cultivars, with an average of 6.6 alleles per locus (ranging from 4 in BPPCT038 to 9 in CPPCT-022). Allele frequencies ranged from 0.004 to 0.846 , with an average of 0.152 ; more than half of these alleles (41) were rare alleles $\left(p_{i} \leq 0.1\right)$. We found 5 markers exhibiting alleles with $p_{i} \geq 0.6$; this would explain why the $\mathrm{H}_{\mathrm{e}}$ of those markers was lower than average (BPPCT-006, BPPCT-007, BPPCT-008, BPPCT-038 and CРPCT-029). For example, the marker BPPCT-008 amplified 6 alleles but one of them was over-represented with $p_{i}=0.846$. Considering all loci under scrutiny, the average $\mathrm{H}_{\mathrm{o}}$ was 0.345 (ranging from 0.145 in BPPCT-008 to 0.573 in PMS-67) and the average $\mathrm{H}_{\mathrm{e}}$ was 0.552 (ranging from 0.276 in BPPCT-008 to 0.813 in CPPCT-022). Consequently, $F$ values were positive with a mean value of 0.374 .

\section{Prunus persica diversity}

A Neighbor Joining dendrogram (Figure 2) based on binary data collected for the 9 markers tested on the complete set of 117 genotypes, showed that peaches and nectarines clustered in 2 independent groups, with the exception of 5 nectarines that were included in the peaches cluster, and 13 peaches included among nectarines. 'September Lady' was classified as a nectarine by the local provider of the sample, but according to the California Department of Food and Agriculture this is a peach cultivar. According to our data, Septermbre Lady clustered with peaches. 'Ivory Princess' and 'Crown Princess', 2 of the peach cultivars found in the nectarines cluster have a nectarine as a parent. 'Ivory Princess' was developed as a first generation cross using 'Crown Princess' yellow flesh peach as the selected seed parent and 'June Pearl', a white flesh nectarine, as the selected pollen donor. 'Crown Princess' was the result of a seedling using 'Red Diamond' nectarine as the selected seed parent and an unknown peach seedling as the pollen parent.

The separation in 2 main clusters is consistent with an independent management of each genetic pool, driven by breeders during many decades. Most of the peaches used in this study were yellow fleshed, but they tend to group separately in clingstone/melting cultivars and freestone/non-melting cultivars. As with peaches, nectarine cultivars were mostly yellow fleshed, but the white fleshed ones tend to group together also. Based on this clustering, the diversity parameters were calculated for peaches and for nectarines separately. Peach cultivars had 51 alleles, 15 of them (29\%) specific to this group; nectarine cultivars, had 44 alleles, $8(18 \%)$ specific to this group. The mean values of $\mathrm{H}_{0}, \mathrm{H}_{\mathrm{e}}$ and $\mathrm{F}$ for the nectarine group were lower compared with the peach group, suggesting a different genetic structure between these groups.

\section{Determination of the optimal SSR combination}

To determine the optimal SSR combination for cultivar identification, the SSR markers were ranked according to the number of observed genotypes (Table 4). Marker CPPCT-022 produced the largest number of observed genotypes $(\mathrm{n}=25)$ and alleles $(\mathrm{n}=9)$. The lowest values for these 2 parameters were determined for markers 
Fingerprinting of peaches and nectarines with SSRS

Table 3. Variability parameters of $P$. persica obtained with 14 SSRs makers in 117 cultivars.

\begin{tabular}{|c|c|c|c|c|c|c|c|}
\hline \multirow{2}{*}{ SSR/cv group } & \multirow{2}{*}{$\begin{array}{l}\text { \# Individuals } \\
\text { scored }\end{array}$} & \multirow{2}{*}{$A^{a}$} & \multirow{2}{*}{$A e^{b}$} & \multirow{2}{*}{$\mathrm{Ho}^{\mathrm{c}}$} & \multirow{2}{*}{$H e^{d}$} & \multirow{2}{*}{$F^{e}$} & \multirow{2}{*}{$\begin{array}{c}\# \\
\text { Genotypes }\end{array}$} \\
\hline & & & & & & & \\
\hline ВРPCT-001 & 117 & 7 & 3,4 & 0,316 & 0,708 & 0,553 & 15 \\
\hline ВРPCT-006 & 117 & 8 & 2,3 & 0,376 & 0,565 & 0,335 & 16 \\
\hline ВPPCT-007 & 117 & 5 & 2,0 & 0,154 & 0,509 & 0,698 & 7 \\
\hline ВРPCТ-008 & 117 & 6 & 1,4 & 0,145 & 0,276 & 0,473 & 9 \\
\hline ВРPCT-038 & 117 & 4 & 1,6 & 0,291 & 0,373 & 0,221 & 7 \\
\hline СРРСТ-022 & 117 & 9 & 5,4 & 0,47 & 0,813 & 0,422 & 23 \\
\hline СРРСТ-029 & 117 & 8 & 2,1 & 0,376 & 0,512 & 0,266 & 13 \\
\hline СРРСТ-030 & 117 & 7 & 2,5 & 0,402 & 0,607 & 0,339 & 10 \\
\hline PMS-67 & 117 & 5 & 2,5 & 0,573 & 0,607 & 0,056 & 9 \\
\hline M & & 6,6 & 2,6 & 0,345 & 0,552 & 0,374 & \\
\hline M peaches & & 5,7 & 2,8 & 0,356 & 0,574 & 0,367 & \\
\hline M nectarines & & 4,9 & 2,2 & 0,331 & 0,463 & 0,350 & \\
\hline
\end{tabular}

$A^{a}$ : Number of alleles; $A_{e}^{b}$ : Effective number of alleles; $H_{0}^{c}$ : Observed heterozygosity

$\mathrm{H}_{\mathrm{e}}^{\mathrm{d}}$ : Expected heterozygosity; $\mathrm{F}^{\mathrm{e}}$ : Wright's Fixation Index; $\mathrm{M}^{\dagger}$ : mean.

BPPCT-038 and BPPCT-007, reaching only 7 observed genotypes and 4 and 5 alleles, respectively.

When using the single marker CPPCT-022, 92 indistinguishable pairs are obtained. As new SSR markers are added to the analysis, the theoretical number of undistinguishable genotypes $\left(X_{k}\right)$ diminishes to finally reach a value of 2.4 (Table 5). When comparing this value with the empirical result, there was a group of 7 pairs of indistinguishable genotypes, a number reached with just the first 7 markers. This means that $10.1 \%$ of the cultivars could not be individually resolved. For this reason, the last 2 markers (BPPCT-007 and BPPCT-038) where discarded and an additional set of 5 markers were tested (CPPCT-002, CPPCT-005, UDP98-410, GA-34 and PS9f8). The result was that any of the markers PS9f8, UDP98-410 and GA-34 could differentiate 'Sparkling May' and 'Summer Diamond'. Also, marker CPPCT-002 identified a polymorphism among 'Ross' and 'Ross Peach', and 'Ruby Diamond' was effectively discriminated respect of the pair 'Burnectwo'/'Burnecthree' with markers CPPCT-005 or GA-34. The following pairs of genotypes: 'Burnectwo'/‘Burnecthree', 'Ryan's Sun'/'Summer Lady', 'Sun Rise'/'Nectarcrest' and 'Halford'/'Sullivan \#4' could not be differentiated by any combination of the whole set of 14 SSR markers tested.

\section{DISCUSSION}

\section{Microsatellite polymorphism}

A total of 117 peach and nectarine cultivars were studied with a basic set of 9 polymorphic SSR, which amplified a total of 59 alleles. The average number of alleles per locus was 6.6 , a value slightly lower than previously reported by Aranzana et al. (2003b) in a population of 212 peach cultivars with 16 SSR markers (7.3), and largely higher than the observed by Sosinski et al. (2000) in a set of 28 peach cultivars with 8 microsatellite markers (2.6), Aranzana et al. (2002) in a set of 24 peach cultivars with 24 polymorphic SSRs (3.2) and Testolin et al. (2000) in a set of 50 peach cultivars with 26 SSR markers (4.5). These differences in information content per marker can be explained by the number of cultivars studied in every case, reflecting the higher chance to find more alleles when the number of genotypes is also higher.

The number of observed alleles per locus in peach was lower (4-9 in this work) than those observed in other fruit 
Table 4. Primer discrimination power (D) and number of observed genotypes and indistinguishable pairs.

\begin{tabular}{|l|c|c|c|c|c|}
\hline \multicolumn{1}{|c|}{ SSR marker } & $\begin{array}{c}\text { \# scored } \\
\text { Individuals }\end{array}$ & Cj & $\mathbf{D}$ & \# Genotypes & $\begin{array}{c}\text { \# of indistinguishable pairs } \\
\text { (observed value) }\end{array}$ \\
\hline CPPCT-022 & 117 & 0,180 & 0,820 & 25 & 92 \\
\hline BPPCT-006 & 117 & 0,430 & 0,570 & 16 & 101 \\
\hline BPPCT-001 & 117 & 0,286 & 0,714 & 15 & 102 \\
\hline CPPCT-029 & 117 & 0,483 & 0,517 & 13 & 104 \\
\hline CPPCT-030 & 117 & 0,387 & 0,613 & 10 & 108 \\
\hline BPPCT-008 & 117 & 0,722 & 0,278 & 9 & 108 \\
\hline PMS-67 & 117 & 0,388 & 0,612 & 9 & 110 \\
\hline BPPCT-007 & 117 & 0,486 & 0,514 & 7 & 110 \\
\hline BPPCT-038 & 117 & 0,624 & 0,376 & 7 & 107 \\
\hline
\end{tabular}

\#: Number.

crops such as apples, which ranged from 6-13 with an average of 9.2 (Galli et al. 2005). On the contrary, it was higher than the value determined in a group of 10 sweet cherry cultivars also studied with 9 SSRs, which ranged from 3-6 with an average of 4.1 (Kaçar et al. 2005). However, this kind of comparisons must take into consideration the number of genotypes under study, and the number of sweet cherry cultivars of the cited paper was too small to allow a valid comparison. This result is in agreement with the narrow genetic background known to peach and nectarine modern varieties, which main source of diversity came from a reduced number of genotypes originally bred in North America by the end of XIX ${ }^{\text {th }}$ century.

The mean $\mathrm{H}_{\mathrm{o}}$ and $\mathrm{H}_{\mathrm{e}}$ values found in our work (0.345 and 0.552 , respectively) were very close to those observed in a previous work by Aranzana et al. (2003b) $(0.350$ and 0.500 , respectively). In this case, the comparison among both results is possible because of the number of genotypes and markers used.

Allele frequency range was quite diverse, ranging from 0.004 to 0.846 with a mean value of 0.152 . A total of 41 rare alleles $\left(p_{i} \leq 0.1\right)$ were found and, by the opposite, six alleles with $p_{i} \geq 0.6$ were identified; both diminished severely the heterozygosity of the harboring loci. The alleles occurring at higher frequencies at each locus could be considered as set points of sequence repeats and new alleles might sequentially derive from them, by increasing or decreasing the number of repetitions (Xu et al. 2000).

\section{Prunus persica diversity}

As mentioned earlier, the dendrogram obtained with our SSR data clearly separate peaches and nectarines into different genetic groups. This is consistent with the breeders practice of not making inter-group crossings. Only a few exceptions to this rule were detected, such as peaches 'Ivory Princess' and 'Crown Princess' that clustered together with nectarines. This "abnormality" could be tentatively explained analyzing the origin of their progenitors; 'Ivory Princess' derives from the cross of 'Crown Princess', a peach, and 'June Pearl', a nectarine. 'Crown Princess' comes from a cross of 'Red Diamond', a nectarine, with an unknown peach cultivar. In any case, both genetic groups are quite alike and to find differences is more difficult than to find genetic similarities.

In spite of that, there were consistent differences between genetic parameters for peaches and nectarines, with nectarines presenting lower diversity indexes expressed in less alleles and in lower values for $\mathrm{H}_{\mathrm{o}}$ and $\mathrm{H}_{\mathrm{e}}$. This could mean that the level of heterozygosity is less in nectarines than in peaches, but the different number of individuals in each population (53 nectarines vs. 64 peaches) could alter this conclusion, as discussed before. A larger sample, with 
Table 5. Selection of the most efficient minimum set of SSR markers for the identification of the 117 different cultivars.

\begin{tabular}{|c|c|c|}
\hline \multirow{2}{*}{ SSR combination } & \multicolumn{2}{|c|}{$\begin{array}{c}\text { \# of } \\
\text { Indistinguishable } \\
\text { pairs }\end{array}$} \\
\hline & $X_{k}$ & $\begin{array}{l}\text { Experimentally } \\
\text { observed }\end{array}$ \\
\hline СРPCT-022 & 1221,5 & 92 \\
\hline СРPCT-022 + ВPPCT-006 & 525,2 & 54 \\
\hline СРРСТ-022 + ВРPСТ-006 + ВРPСТ-001 & 150,2 & 23 \\
\hline СРРСТ-022 + ВРPСТ-006 + ВРPСТ-001 + СРPСТ-029 & 72,6 & 17 \\
\hline СРPСТ-022 + ВРPСТ-006 + ВРPСТ-001 + СРPСТ-029 + СРPСТ-030 & 28,1 & 14 \\
\hline 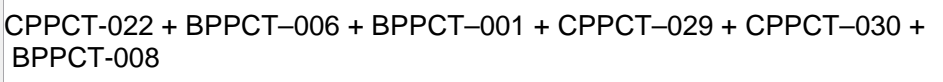 & 20,3 & 10 \\
\hline $\begin{array}{l}\text { CPPCT-022 + BPPCT-006 + BPPCT-001 + СPPCT-029 + CPPCT-030 + } \\
\text { ВPPCT-008 + PMS-67 }\end{array}$ & 7,9 & 7 \\
\hline $\begin{array}{l}\text { СРPCT-022 + BPPCT-006 + ВPPCT-001 + СРPCT-029 + СРPCT-030 + } \\
\text { ВPPCT-008 + PMS-67 + BPPCT-007 }\end{array}$ & 3,8 & 7 \\
\hline $\begin{array}{l}\text { СРPCT-022 + BPPCT-006 + ВPPCT-001 + СРPCT-029 + СРPСТ-030 + } \\
\text { ВPPCT-008 + PMS-67 + ВPPCT-007 + ВPPCT-038 }\end{array}$ & 2,4 & 7 \\
\hline
\end{tabular}

\#: Number.

equal number of peaches and nectarines, may be required to confirm this assumption.

\section{Cultivar identification}

The use of this particular set of SSR markers allows us to differentiate $88.9 \%$ of the analyzed cultivars; 7 of the 9 SSR markers tested showed high discriminating power, confirming the high efficiency of this type of marker for cultivar identification. These results are similar at some extent to those reported by Aranzana et al. (2003b), who were able to differentiate $87 \%$ of 212 cultivars of European origin with 16 SSR markers, which includes the markers used in this work. In comparison, 66 apple cultivars (excluding cultivars derived from clonal mutations, such as those of 'Fuji' or 'Gala') were discriminated using just 4 SSR markers (Galli et al. 2005); in sweet cherries, 68 cultivars $(89.5 \%$ of the studied population) were discriminated using 9 SSR markers (Wünsch and Hormaza, 2002); and 224 grapevine cultivars were differentiated using 8 markers, but in this combining 6 RAPD (dominant) plus 2 SSR (co-dominant) markers (Tessier et al. 1999). These values suggest that peaches and nectarines are not much less diverse in comparison to other fruit crops, but this comparison is difficulted because in each case the criteria for the selection of the markers could have been different or less stringent, or in any way biased. So, the only conclusion possible to be done at this point is that the varieties of this stone fruit are possible to be differentiated with yields similar to other fruit crops, if the SSR markers are carefully selected.

The selection of markers will depend on the nature of the germplasm under study. In our case, the existence of a set of markers applied for the identification of Spanish germplasm was useful but not totally transferable to the Chilean peaches and nectarines varietal collection. A bis- $a-$ bis comparison of markers used in both cases revealed that some markers were the most informative in both germplasm collections, notably CPPCT-022, BPPCT-006, BPPCT-001 and some others. However, the hierarchy of "quality" was different among this work and the one based on Spanish cultivars (Aranzana et al. 2003b). For example, marker CPPCT-029 was the fourth most informative in the case of the Chilean varieties, but was only the $10^{\text {th }}$ in the case of varieties from Spain. This result confirms that the validation of a set of SSR markers for the fingerprinting of a particular species requires the evaluation of a set of genotypes that represent the largest possible genetic 
Rojas, G. et al.

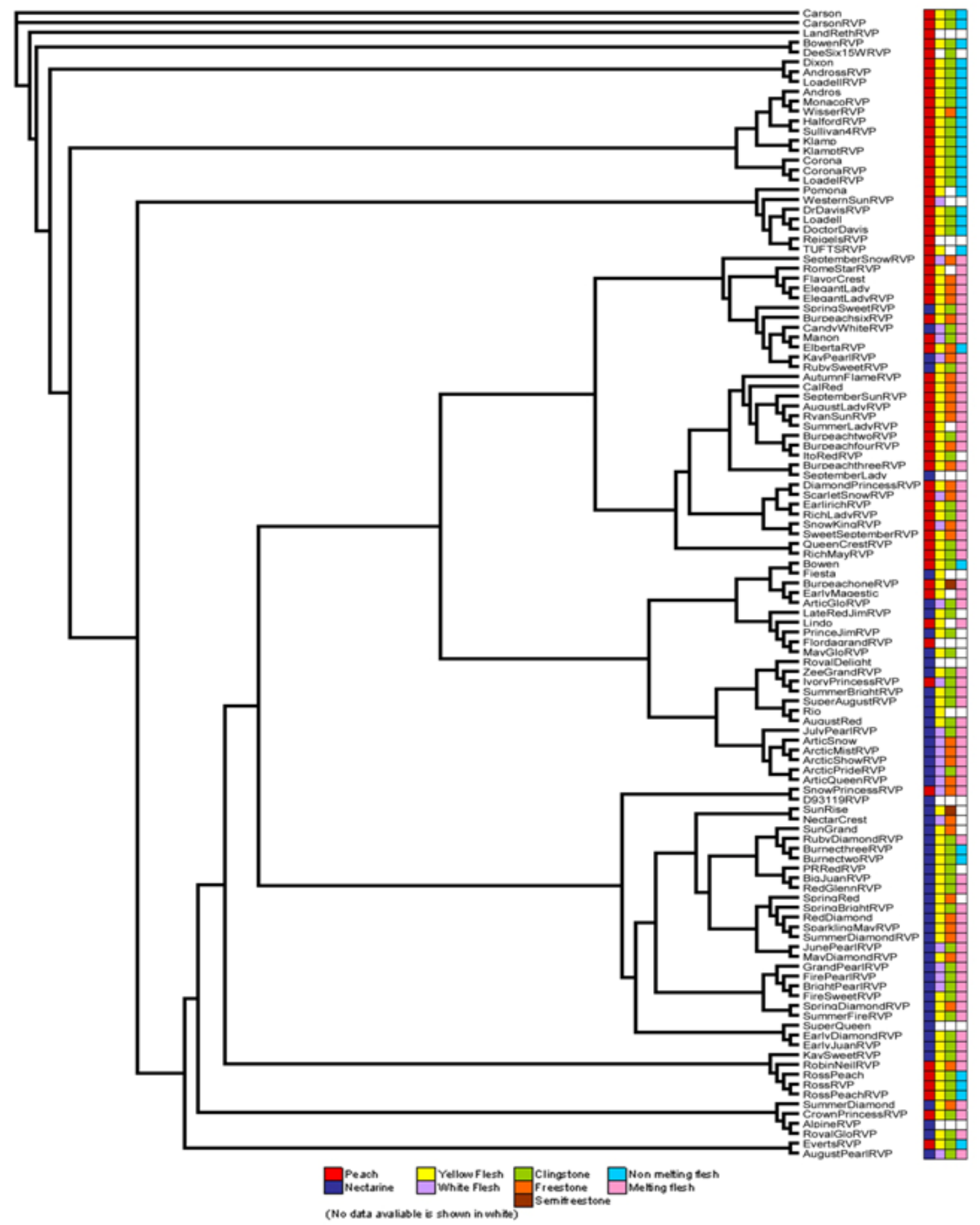

Figure 2. Neighbor joining dendogram of 117 P. persica cultivars based on their variation at 9 SSR loci. The color keys refer to peach/nectarine, flesh color, clingstone type and melting/non-melting type, as indicated.

diversity of the species of interest. The most stricking result presented here, in comparison with previous works on peach and nectarine cultivars differentiation, is the identification and validation of this set of 7 SSR markers (Table 4), information that could be very valuable for nurserymen who requires to maintain the "genetic quality" (true-to-typeness and homogeneity) of their genetic stocks.

Some cultivars were not distinguishable using the set of 9 markers. For example, 'Sparkling May' and 'Summer 
Diamond', both siblings of 'Red Diamond', could only be differentiated with an additional set of markers. The same was true to diferenciate 'Ross', 'Ross Peach' and 'Ruby Diamond' from 'Burnectwo' and 'Burnecthree'. However, the last two cultivars, that share the same origin (siblings of the nectarines cross 'Grand Diamond' X 'Flameglo'), were not differentiated, even when testing a larger set of markers (results not shown). The same occurred in the following pairs: 'SunRise'/'NectarCrest', 'Halford'/'Sullivan \#4' and 'Ryan's Sun'/'Summer Lady' (mutations derived from 'O'Henry'). In order to differentiate these 6 cultivars organized as pairs ('Burnectwo'/'Burnecthree', 'SunRise'/'NectarCrest' y 'Halford'/'Sullivan \#4'), a larger number of SSRs may be needed. In the case of 'Ryan's Sun' and 'Summer Lady' that are mutations of the same cultivar, this approach may not work at all, and alternative techniques, such as AFLP or S-SAP may become necessary.

\section{ACKNOWLEDGMENTS}

The collaboration of Manuel Toro, from the Chilean Registry of Protected Varieties (RVP) of the Servicio Agrícola y Ganadero, Ministry of Agriculture, and of the Chilean nurserymen who provided the genetic material required for this study is greatly acknowledged.

\section{REFERENCES}

ARANZANA, M.J.; GARCÍA-MAS, J.; CARBÓ, J. and ARÚS, P. Development and variability analysis of microsatellite markers in peach. Plant Breeding, February 2002, vol. 121, no. 1, p. 87-92.

ARANZANA, M.J.; PINEDA, A.; COSSON, P.; DIRLEWANGER, E.; ASCASIBAR, J.; CIPRIANI, G.; RYDER, C.D.; TESTOLIN, R.; ABBOTT, A.; KING, G.J.; IEZZONI, A.F. and ARÚS; P. A set of simple-sequence repeat (SSR) markers covering the Prunus genome. Theoretical and Applied Genetics, March 2003a, vol. 106, no. 5 , p. 819-825.

ARANZANA, M.J.; CARBÓ, J. and ARÚS, P. Microsatellite variability in peach [Prunus persica (L.) Batsch]: cultivar identification; marker mutation; pedigree inferences and population structure. Theoretical and Applied Genetics, May 2003b, vol. 106, no. 8, p. 13411352.

CANTINI, C.; IEZZONI, A.; LAMBOY, W.; BORITZKI, M. and SRTUSS, D. DNA fingerprinting of tetraploid cherry germplasm using simple sequence repeats. Journal of the American Society for Horticultural Science, March 2001, vol. 126, no. 2, p. 205-209.

CIPRIANI, G.; LOT, G.; HUANG, W.-G.; MARRAZZO, M.T.; PETERLUNGER, E. and TESTOLIN, R. AC/GT and $\mathrm{AG} / \mathrm{CT}$ microsatellite repeats in peach (Prunus persica
(L) Batsch): isolation; characterisation and cross-species amplification in Prunus. Theoretical and Applied Genetics, July 1999, vol. 99, no. 1-2, p. 65-72.

CRESTE, S.; TULMANN NETO, A. and FIGUEIRA, A. Detection of simple sequence repeats polymorphisms in denaturating polyacrylamide sequencing gels by silver staining. Plant Molecular Biology Reporter, December 2001, vol. 19, no. 4, p. 299-306.

DECROOCQ, V.; HAGEN, L.; FAVÉ, M-G.; EYQUARD, J.-P. and PIERRONNET, A. Microsatellite markers in the hexaploid Prunus domestica species and parentage lineage of three European plum cultivars using nuclear and chloroplast simple-sequence repeat. Molecular Breeding, February 2004, vol. 13, no. 2, p. 135-142.

DIRLEWANGER, E.; COSSON, P.; TAVAUD, M.; ARANZANA, M.J.; POIZAT, C.; ZANETTO, A.; ARÚS, P. and LAIGRET, F. Development of microsatellite markers in peach [Prunus persica (L.) Batsch] and their use in genetic diversity analysis in peach and sweet cherry (Prunus avium L.). Theoretical and Applied Genetics, July 2002, vol. 105, no. 1, p. 127-138.

DIRLEWANGER, E.; GRAZIANO, E.; JOOBEUR, T.; GARRIGA-CALDERÉ, F.; COSSON, P.; HOWARD, W. and ARÚS, P. Comparative mapping and marker-assisted selection in Rosaceae fruit crops. Proceedings of the National Academy of Science of the United States of America, June 2004, vol. 101, no. 26, p. 9891-9896.

DOWNEY, S.L. and IEZZONI, A.F. Polymorphic DNA markers in black cherry (Prunus serotina) are identified using sequences from sweet cherry; peach; and sour cherry. Journal of the American Society for Horticultural Science, January 2000 , vol. 125 , no. 1, p. 76-80.

FIDEGHELLI, C.; DELLA STRADA, G.; GRASSI, F. and MORRICO, G. The peach industry in the world: present situation and trend. Acta Horticulturae, April 1998, vol. 465 , no. 1 , p. $29-40$.

FOOLAD, M.R.; ARULSEKAR, S.; BECERRA, V. and BLISS, F.A. A genetic map of Prunus based on an interspecific cross between peach and almond. Theoretical and Applied Genetics, July 1995, vol. 91, no. 2, p. 262-269.

GALLI, Z.; HALASZ, G.; KISS, E. and HESZKY, L. Molecular identification of commercial apple cultivars with microsatellite markers. Hortscience, December 2005, vol. 40, no. 7, p. 1974-1977.

HOWAD, W.; YAMAMOTO, T.; DIRLEWANGER, E.; TESTOLIN, R.; COSSON, P.; CIPRIANI, G.; MONFORTE, A.J.; GEORGI, L.; ABBOT, A. and ARÚS, P. Mapping with a few plants: using selective mapping for microsatellite saturation of the Prunus reference map. Genetics, November 2005, vol. 171, no. 3, p. 1305-1309. 
KAÇAR, Y.; IEZZONI, A. and CETINER, S. Sweet cherry cultivar identification by using SSR markers. Journal of Biological Sciences, 2005, vol. 5, no. 5, p. 616-619.

LODHI, M.A.; YE, G-N.; WEEDEN, N.F. and REISCH, B.I. A simple and efficient method for DNA extraction from grapevine cultivars and Vitis species. Plant Molecular Biology Reporter, March 1994, vol. 12, no. 1, p. 6-13.

MESSINA, R.; LAIN, O.; MARRAZZO, M.T.; CIPRIANI, R. and TESTOLIN, R. New set of microsatellite loci isolated in apricot. Molecular Ecology Notes, September 2004, vol. 4, no. 3, p. 432-434.

MNEJJA, M.; GARCIA-MAS, J.; HOWAD, M.; BADENES, M.L. and ARÚS, P. Simple-sequence repeat (SSR) markers of Japanese plum (Prunus salicina Lindl.) are highly polymorphic and transferable to peach and almond. Molecular Ecology Notes, June 2004, vol. 4, no. 2, p. 163-166.

MORGANTE, M. and OLIVIERI, A. PCR-amplified microsatellites as markers in plant genetics. Plant Journal, January 1993, vol. 3, no. 1, p. 175-182.

SCORZA, R.; MEHLENBACHER, S.A. and LIGHTNER, G.W. Inbreeding and coancestry of freestone peach cultivars of the Eastern United States and implications for peach germoplasm improvement. Journal of the American Society for Horticultural Science, 1985, vol. 110, no. 4, p. 547-552.

SCORZA, R.; SHERMAN, W.B. and LIGHTNER, G.W. Inbreeding and co-ancestry of low chill short fruit development period freestone peaches and nectarines produced by the University of Florida breeding program. Fruit Varieties Journal, 1988, vol. 43, no. 3, p. 79-85.

SOSINSKI, B.; GANNAVARAPU, M.; HAGER, L.D.; BECK, E.; KING, G.J.; RYDER, C.D.; RAJAPAKSE, S.; BAIRD, W.V.; BALLARD, R.E. and ABBOTT, A.G. Characterization of microsatellite markers in peach [Prunus persica (L.) Batsch]. Theoretical and Applied Genetics, August 2000, vol. 101, no. 3, p. 421-428.

SWOFFORD, D.L. PAUP Phylogenetic Analysis Using Parsimony (*And Other Methods). Sinauer Associates; Sunderland; Massachusets. 1998.

TESSIER, C.; DAVID, J.; THIS, P.; BOURSIQUOT, J.M. and CHARRIER; A. Optimization of the choice of molecular markers for varietal identification in Vitis vinifera L. Theoretical and Applied Genetics, January 1999, vol. 98, no. 1, p. 171-177.

TESTOLIN, R.; MARRAZZO, T.; CIPRIANI, G.; QUARTA, R.; VERDE, I.; DETTORI, M.T.; PANCALDI, $M$. and SANSAVINI, S. Microsatellite DNA in peach (Prunus persica (L.) Batsch) and its use in fingerprinting and testing the genetic origin of cultivars. Genome, June 2000, vol. 43, no. 3, p. 512-520.

TESTOLIN, R.; MESSINA, R.; LAIN, O.; MARRAZO, M.T.; HUANG, W.-G. and CIPRIANI, G. Microsatellites isolated in almond from an AC-repeated enriched library. Molecular Ecology Notes, September 2004, vol. 4, no. 3, p. 459-461.

VAUGHAN, S.P. and RUSSELL, K. Characterization of novel microsatellites and development of multiplex PCR for large-scale population studies in wild cherry; Prunus avium. Molecular Ecology Notes, September 2004, vol. 4, no. 3, p. 429-431.

WÜNSCH, A. and HORMAZA, J.I. Molecular characterization of sweet cherry (Prunus avium L.) genotypes using peach (Prunus persica (L) Batsch) SSR sequences. Heredity, July 2002, vol. 89, no. 1, p. 56-63.

XU, X.; PENG, M.; FANG, Z. and XU, X. The direction of microsatellite mutations is dependent upon allele length. Nature Genetics, April 2000, vol. 24, no. 4, p. 396-399. 